\title{
BMJ Open Association between vitamin D and uterine fibroids: a study protocol of an open-label, randomised controlled trial
}

\author{
Bo Sheng, ${ }^{1}$ Yizuo Song, ${ }^{1}$ Yi Liu, ${ }^{1}$ Chenchen Jiang, ${ }^{2}$ Xueqiong Zhu (i) ${ }^{1}$
}

To cite: Sheng B, Song $Y$, Liu Y, et al. Association between vitamin $\mathrm{D}$ and uterine fibroids: a study protocol of an open-label, randomised controlled trial. BMJ Open 2020;10:e038709. doi:10.1136/ bmjopen-2020-038709

- Prepublication history for this paper is available online. To view these files, please visit the journal online (http://dx.doi org/10.1136/bmjopen-2020038709).

BS and YS contributed equally.

Received 25 March 2020

Revised 15 June 2020

Accepted 08 October 2020
Check for updates

(c) Author(s) (or their employer(s)) 2020. Re-use permitted under CC BY-NC. No commercial re-use. See rights and permissions. Published by BMJ.

${ }^{1}$ Department of Obstetrics and Gynecology, the Second Affiliated Hospital of Wenzhou Medical University, Wenzhou, Zhejiang, China

${ }^{2}$ Clinical Research Center, Wenzhou Medical University Second Affiliated Hospital, Wenzhou, China

Correspondence to Dr Xuegiong Zhu; zjwzzxq@163.com

\section{ABSTRACT}

Introduction Uterine fibroids are the most common pelvic benign tumour with no satisfactory long-term medical treatment. Recent studies have demonstrated that vitamin D significantly inhibited the growth of fibroids in vitro, vivo and a small-sample clinical trial. Therefore, the aim of this randomised clinical trial (RCT) is to evaluate whether supplementation with vitamin $\mathrm{D}$ could reduce the risk and inhibit the growth of uterine fibroids in reproductive stage women.

Methods and analysis The open-label, RCT comprises two parts, including parts I and II. In part I, 2230 vitamin $D$ deficiency or vitamin $D$ insufficiency patients without uterine fibroids will be randomly assigned to two groups: intervention group (according to the level of serum 25-hydroxyvitamin $D_{3}$, receive 1600 or $800 \mathrm{lU} /$ day of vitamin $D_{3}$ for 2 years) and control group (followed up at the same time points). By using gynaecological ultrasound examinations, the incidence of uterine fibroids will be employed to measure the outcome in different groups. In part II, 360 uterine fibroids patients with vitamin D deficiency or vitamin $D$ insufficiency will be randomly assigned to intervention group or control group. According to the level of serum 25 -hydroxyvitamin $D_{3}, 180$ patients will receive 1600 or $800 \mathrm{lU} /$ day of vitamin $\mathrm{D}_{3}$ for 2 years. Control group will receive regular follow-up. The outcome measure will be conducted using gynaecological ultrasound examinations to detect the growth of uterine fibroids in each group.

Ethics and dissemination This study has been approved by the institutional review board of the Second Affiliated Hospital of Wenzhou Medical University (No. LCKY201835).

Trial registration numbers NCT03586947 and NCT03584529.

\section{INTRODUCTION}

Uterine fibroids (UFs) are the most common benign tumour of the female genital tract, originating from smooth muscle cells. ${ }^{1}$ Due to diverse diagnostic methods and the population source in many epidemiological studies, the incidence of leiomyomas ranges from $5.4 \%$ to $77 \%$ of women in their reproductive years. ${ }^{1}$ Because most patients with UFs remain asymptomatic, the actual incidence of UFs is assumed to be much higher than that reported. Based on the ultrasound

\section{Strengths and limitations of this study}

The results from this randomised clinical trial will provide new evidences of the efficacy and safety of vitamin $\mathrm{D}$ for uterine fibroids patients.

- One limitation is that the trial is not a double-blind, placebo-controlled trial and implemented in only one hospital.

- Another limitation is that the trial is implemented in only one hospital in Chinese subjects, which may limit its generalisability.

screening, the incidence for UFs is reported to be $1.278 \%$ in Asia and $3.745 \%$ in AfricanAmerican women per year. ${ }^{1}$ The common symptoms of UFs include heavy menstrual bleeding, menstrual disorders and pelvic discomfort. ${ }^{2}$ Furthermore, UFs are also associated with infertility and early pregnancy loss. The treatment for UFs depends on the size, location, symptoms, age and reproductive plans. Surgery is still the major treatment for symptomatic UFs including hysterectomy and myomectomy. ${ }^{3} 4$ Uterine arterial embolisation, one of the conservative interventional treatments with the longest track record, has become the major second line option for UFs patients who are properly selected. ${ }^{34}$ However, these therapies increase the patients' operative complications and generates huge economic impact on healthcare systems. Except invasive surgical procedure, gonadotropin-releasing hormone agonist $(\mathrm{GnRHa})^{56}$ (eg, leuprorelin) and mifepristone ${ }^{78}$ are the most commonly used medical agents for UFs in China. When these two drugs are stopped, UFs may regrow rapidly. ${ }^{9}$ Thus, GnRHa or mifepristone is usually used for the clinically symptomatic patients who are at a perimenopausal period, or who have contraindications of surgery. Selective progesterone receptor modulators (SPRMs) act by linkage with progesterone receptors in the smooth muscle of UFs, leading to inhibition of cell proliferation. ${ }^{11}$ 
In fact, mifepristone is the first SPRM approved to treat UFs. ${ }^{12}$ In addition to mifepristone, four types of SPRMs have been developed including asoprisnil, telapristone acetate, ulipristal acetate and vilaprisan. ${ }^{13}$ However, these four SPRMs have not been licensed in China to date and are still being investigated in human clinical trials. ${ }^{14}$ Therefore, it is still paramount to finding a novel nonsurgical alternative for UFs patients and prevent their occurrence.

Vitamin D is one of the essential nutrients for human bodies. Recent studies have considered that vitamin $\mathrm{D}$ is involved in the development of UFs. ${ }^{101516}$ For example, two groups have demonstrated that low levels of serum 25-hydroxyvitamin $\mathrm{D}_{3}$ are linked with increased risk of UFs. ${ }^{17}{ }^{18}$ Bläuer $e t a l^{19}$ found that the growth of both primary myometrial and leiomyoma cells could be inhibited by 1,25-dihydroxyvitamin $\mathrm{D}_{3}$ in a concentrationdependent way. Moreover, the process of fibrosis induced by the transforming growth factor- $\beta 3$ (TGF- $\beta 3$ ) could be attenuated by vitamin $\mathrm{D}$ in immortalised human UFs (HuLM) cells. In addition, vitamin D suppressed the protein expression of plasminogen activator inhibitor-1, which is an important TGF- $\beta$ target in HuLM cells. ${ }^{20}$ Such inhibitory effect of vitamin D on UFs is also verified in several in vivo studies. Halder $e t a l^{21}$ reported that 1,25-dihydroxyvitamin $\mathrm{D}_{3}$ decreased fibroid tumour size through downregulation of proliferation-related genes, antiapoptotic genes, oestrogen and progesterone receptors in Eker rats. Two years later, Halder $e t a l^{22}$ further found that the treatment with 1,25-dihydroxyvitamin $\mathrm{D}_{3}$ or paricalcitol, an analogue of 1,25-dihydroxyvitamin $\mathrm{D}_{3}$ with lower calcemic activity, could reduce tumour size in mouse xenograft models of UFs. Most recently, one study by Corachán $e t a l^{23}$ demonstrated that vitamin D inhibited the proliferation of human primary uterine leiomyoma cells via cell growth arrest induction and Wnt/ $\beta$-catenin pathway downregulation. Furthermore, long-term vitamin $\mathrm{D}$ treatment significantly decreased the uterine leiomyoma size in a xenograft ovariectomised nonobese diabetic-severe combined immunodeficiency disease (NOD-SCID) mouse model, ${ }^{24}$ which confirmed the inhibitory effect of vitamin D on UFs growth in vivo.

Our group has demonstrated that serum 25-hydroxyvitamin $\mathrm{D}_{3}$ level was significantly lower in patients with UFs as compared with controls. In addition, patients with vitamin D deficiency had increased risks of UFs. ${ }^{25}$ An open-label clinical trial indicated that the supplement of vitamin D in women with UFs stabilised the growth of fibroids and prevented the onset of its related symptoms. ${ }^{26}$ But it was not a randomised trial and only 108 patients were included in the trail. A recently published randomised clinical trial found that vitamin D consumption did not significantly decrease the volume of fibroids in experimental group compared with control group. ${ }^{27}$ However, this new trial was completed shortly with a follow-up period of only 12 weeks. Hence, it is still unclear whether long-term supplementation of vitamin D could decrease the risk or inhibit the growth of UFs.
Therefore, we aim to conduct a randomised clinical trial and evaluate the effect and safety of administration with vitamin $\mathrm{D}$ on decreasing the risk and inhibiting the development of UFs in reproductive-aged women.

\section{METHODS AND ANALYSIS}

\section{Study design}

This is an open-label, randomised controlled trial. The study contains two parts (part I and part II) and will be conducted between 31 May 2020 and 1 October 2022 in the Second Affiliated Hospital of Wenzhou Medical University, a hospital in China. Part I is to investigate the effect of supplementation with vitamin D on the risk of UFs. Part II is about the association between vitamin D supplementation and the development of UFs. The regimen of vitamin $\mathrm{D}$ doses from several international guidelines and important published clinical trials are listed in table 1.

\section{Part I: efficacy of vitamin D on the risk of UFs Study objectives}

The primary objective of this part is to assess the efficacy of supplementation with vitamin $\mathrm{D}$ on decreasing the risk of incident UFs within 1 year and 2 years. The secondary objective of this study is to evaluate the safety of supplementation with vitamin $\mathrm{D}$ in subjects.

\section{Trial design}

This is an open-label, randomised controlled trial. After signing of informed consent, vitamin $\mathrm{D}$ deficiency patients $\left(12 \mathrm{ng} / \mathrm{mL} \leq\right.$ serum 25-hydroxyvitamin $\left.\mathrm{D}_{3} \leq 20 \mathrm{ng} / \mathrm{mL}\right)$ without UFs will be randomly assigned in a 1:1 ratio to either the intervention group A or the control group B. Intervention group A will receive an oral dose of $1600 \mathrm{IU}$ (four capsules) /day vitamin $\mathrm{D}_{3}$ for up to 2 years. Control group $B$ will receive 2 years follow-up. Patients with vitamin D insufficiency $(21 \mathrm{ng} / \mathrm{mL}$ s serum 25-hydroxyvitamin $\mathrm{D}_{3} \leq 29 \mathrm{ng} / \mathrm{mL}$ ) without UFs will be randomly assigned in a 1:1 ratio to intervention group $\mathrm{C}$ or control group D. Intervention group $\mathrm{C}$ will accept an oral dose of $800 \mathrm{IU}$ (two capsules)/day vitamin $\mathrm{D}_{3}$ for up to 2 years. Control group D will receive 2 years follow-up. Gynaecological ultrasound examinations will be performed every 6 months. The number, location and size of the UFs will be documented. The safety of subjects will be evaluated, including blood routine examination, electrolyte, hepatic and renal function, liver and urinary system ultrasound, and serum 25-hydroxyvitamin $\mathrm{D}_{3}$. Vitamin $\mathrm{D}$ receptor genotype of all patients will also be tested. Vitamin $\mathrm{D}_{3}$ soft capsules (400 IU per capsule) are purchased from Sinopharm star shark pharmaceutical (Xiamen, China) and can be preserved for 2 years. An overview of the study design is shown in figure 1 and table 2.

\section{Sample size}

The planned sample size is estimated based on the data from a previous study, in which the UFs incidence was 
Table 1 The doses of vitamin D supplementation in different clinical trials published since 2010

\begin{tabular}{|c|c|c|c|c|c|}
\hline Group & Country & Population & Age (years) & Oral vitamin D & Reference \\
\hline Holick et al & USA & General population & $>19$ & $\begin{array}{l}\text { Risk of vitamin D deficiency: } 1500- \\
2000 \text { IU/day; vitamin D deficiency: } \\
50000 \text { IU/wk for } 8 \text { weeks, followed by } \\
\text { maintenance therapy of } 1500-2000 \text { IU/ } \\
\text { day }\end{array}$ & 32 \\
\hline $\begin{array}{l}\text { de Boer } \\
\text { et al }\end{array}$ & USA & $\begin{array}{l}\text { Participants with type } 2 \\
\text { diabetes }\end{array}$ & $\begin{array}{l}\text { Men aged } \\
\geq 50 \text { and women } \\
\text { aged } \geq 55\end{array}$ & $\begin{array}{l}\text { Vitamin } \mathrm{D}_{3} \text { (cholecalciferol } 2000 \text { IU/day) } \\
\text { and matching inert placebo }\end{array}$ & 38 \\
\hline Burt et al & Canada & $\begin{array}{l}\text { Healthy adults without } \\
\text { osteoporosis }\end{array}$ & $55-70$ & $\begin{array}{l}\text { Vitamin } D_{3} \text { at } 400 \mathrm{IU} / \text { day }(n=109) \text {, or } \\
4000 \mathrm{IU} / \text { day }(n=100) \text {, or } 10000 \mathrm{IU} / \text { day } \\
(n=102) \text { for } 3 \text { years }\end{array}$ & 39 \\
\hline $\begin{array}{l}\text { Urashima } \\
\text { et al }\end{array}$ & Japan & $\begin{array}{l}\text { Patients with digestive tract } \\
\text { cancers ovarall }\end{array}$ & 30-90 & $\begin{array}{l}\text { Vitamin D } 2000 \text { IU/day and matching } \\
\text { placebo }\end{array}$ & 40 \\
\hline Aglipay et al & Canada & Children & $1-5$ & $\begin{array}{l}\text { Vitamin D at doses of } 2000 \mathrm{IU} / \text { day } \\
(\mathrm{n}=349) \text { and } 400 \mathrm{IU} / \text { day }(n=354)\end{array}$ & 42 \\
\hline $\begin{array}{l}\text { Zittermann } \\
\text { et al }\end{array}$ & Germany & Heart failure patients & $18-79$ & $\begin{array}{l}\text { Patient with serum } 25 \text {-hydroxyvitamin } \\
D_{3} \text { level }<75 \mathrm{nmol} / \mathrm{L} \text { were randomised } \\
\text { to receive } 4000 \mathrm{IU} / \text { day vitamin } \mathrm{D} \text { or } \\
\text { matching placebo for } 3 \text { years }\end{array}$ & 43 \\
\hline Lappe et al & USA & Postmenopausal women & $\geq 55$ & $\begin{array}{l}\text { Treatment group: } 2000 \mathrm{IU} / \text { day vitamin } \mathrm{D}_{3} \\
\text { and } 1500 \mathrm{mg} / \text { day calcium; The placebo } \\
\text { group: identical placebos }\end{array}$ & 44 \\
\hline Arora et al & USA & $\begin{array}{l}\text { Low vitamin D status } \\
\text { ( } 25 \text {-hydroxyvitamin D levels } \\
\leq 25 \mathrm{ng} / \mathrm{mL} \text { ) patients with SBP } \\
\text { of } 120-159 \mathrm{~mm} \mathrm{Hg}\end{array}$ & $18-50$ & $\begin{array}{l}\text { High-dose group: } 4000 \text { IU/day for } 6 \\
\text { months; low-dose group: } 400 \text { IU/day for } \\
6 \text { months }\end{array}$ & 45 \\
\hline
\end{tabular}

SBP, systolic blood pressure.

$1.278 \%$ per year in Asia and $3.745 \%$ per year in AfricanAmerican women. Women over the age of 40 years are more likely to have UFs. ${ }^{1}$ A study also revealed that African-American females had lower level of serum 25-hydroxyvitamin $\mathrm{D}_{3}$ as compared with Caucasian females. ${ }^{28}$ Vitamin D deficiency is shown to increase the risk of UFs in vitro, in vivo animal models and in a smallsample clinical trial. We assume a one-tailed $\alpha$ error of 0.05 and a power (1- $\beta$ ) of 0.8 . If the rates are $3.745 \%$ for the control group and $1.278 \%$ for the intervention group, we allow for a dropout rate of $10 \%$ for an effective sample size of 2108 and propose to enrol 2320 participants (580 randomised to each arm).

\section{Inclusion criteria}

1. Volunteers to participate in the study with an informed consent.

2. Married females aged 35-50 who are confirmed with a normal, fibroid-free uterine structure, by means of transvaginal ultrasonography.

3. Serum 25-hydroxyvitamin $\mathrm{D}_{3} \geq 12 \mathrm{ng} / \mathrm{mL}, \leq 29 \mathrm{ng} / \mathrm{mL}$.

\section{Exclusion criteria}

1. Women with serum 25-hydroxyvitamin $\mathrm{D}_{3}<12 \mathrm{ng} / \mathrm{mL}$ or $>29 \mathrm{ng} / \mathrm{mL}$.

2. Body mass index $(\mathrm{BMI})<18.5 \mathrm{~kg} / \mathrm{m}^{2}$ or $\mathrm{BMI}>25 \mathrm{~kg} /$ $\mathrm{m}^{2}$.

3. Use of sexual hormone, mifepristone, GnRHa or other medications, which are likely to interfere with UFs in the past 3 months.

4. Pregnancy, lactation, postmenopause or planned pregnancy within 2 years.

5. Allergic to vitamin $\mathrm{D}_{3}$ soft capsules.

6. Suspected or identified as other tumours of genital tract.

7. History of hysterectomy or myomectomy.

8. History of osteoporosis or vitamin D deficiency taking vitamin D supplements constantly within previous 1 month.

9. History of hyperparathyroidism, infectious diseases (tuberculosis, AIDS), autoimmune diseases or 


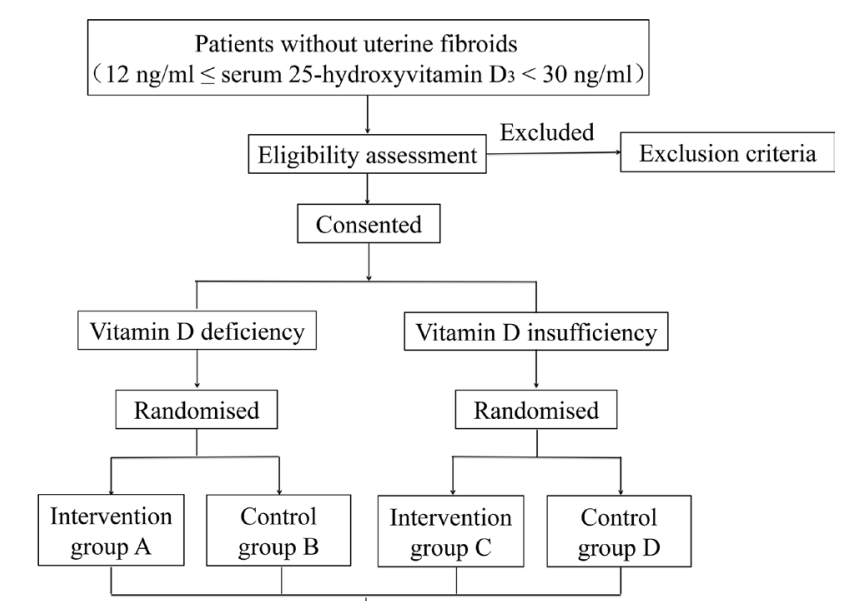

Two years follow-up
Outcomes assessment at 12 and 24 months
(Primary outcomes: the first diagnosis of UFs in different groups; Secondary
outcomes: the safety of supplementation with vitamin D in subjects)
Statistical analysis

Figure 1 Flow chart showing the steps of part I in participant recruitment, treatment and analysis. UFs, uterine fibroids.

digestive system diseases (malabsorption, Crohn's disease and dysentery).

10. Alanine aminotransferase (ALT) or aspartate transaminase (AST) more than 3 times of the normal

Table 2 Flow chart of the study showing timing collection of different variables

\begin{tabular}{|c|c|c|c|c|c|c|c|c|c|}
\hline Follow-up (times) & 1 & 2 & 3 & 4 & 5 & 6 & 7 & 8 & 9 \\
\hline Time points (months) & 0 & 3 & 6 & 9 & 12 & 15 & 18 & 21 & 24 \\
\hline Informed consent & $x$ & & & & & & & & \\
\hline Medical history & $x$ & & & & & & & & \\
\hline Physical examination & $x$ & $x$ & $x$ & $x$ & $x$ & $x$ & $x$ & $x$ & $x$ \\
\hline $\begin{array}{l}\text { Serum } \\
\text { 25-hydroxyvitamin } D_{3}\end{array}$ & $x$ & $x$ & $x$ & $x$ & $x$ & $x$ & $x$ & $x$ & $x$ \\
\hline Urine pregnancy test & $x$ & $x$ & $x$ & $x$ & $x$ & $x$ & $x$ & $x$ & $x$ \\
\hline Gynecologic ultrasound & $x$ & & $x$ & & $x$ & & $x$ & & $x$ \\
\hline $\begin{array}{l}\text { Hepatic and renal } \\
\text { function }\end{array}$ & $x$ & & $x$ & & $x$ & & $x$ & & $x$ \\
\hline
\end{tabular}

$\begin{array}{llllll}\text { Electrolyte } & \mathrm{x} & \mathrm{x} & \mathrm{x} & \mathrm{x} & \mathrm{x} \\ \begin{array}{l}\text { Blood routine } \\ \text { examination }\end{array} & \mathrm{x} & \mathrm{x} & \mathrm{x} & \mathrm{x} & \mathrm{x}\end{array}$

\begin{tabular}{|c|c|c|c|c|c|c|c|c|}
\hline $\begin{array}{l}\text { Liver and urinary } \\
\text { system ultrasound }\end{array}$ & $x$ & & & $x$ & & & & $x$ \\
\hline Side effect assessment & $x$ & $x$ & $x$ & $x$ & $x$ & $x$ & $x$ & $x$ \\
\hline $\begin{array}{l}\text { Changes in } \\
\text { menstruation }\end{array}$ & $x$ & $x$ & $x$ & $x$ & $x$ & $x$ & $x$ & $x$ \\
\hline Adverse event & $x$ & $x$ & $\mathrm{x}$ & $x$ & $\mathrm{x}$ & $x$ & $x$ & $\mathrm{x}$ \\
\hline
\end{tabular}

assessment

Vitamin D receptor $\quad \mathrm{x}$
genotype

upper limit, total bilirubin (TBIL) more than 2 times of the normal upper limit.

11. Creatinine levels $\geq 1.4 \mathrm{mg} / \mathrm{dL}(123 \mu \mathrm{mol} / \mathrm{l})$ or creatinine clearance $\leq 50 \mathrm{~mL} / \mathrm{min}$.

12. History of malignant tumours.

13. Simultaneous participation in another clinical study with investigational medicinal product(s).

\section{Outcomes measures}

The primary outcome is the first diagnosis of UFs in different groups. The secondary outcomes include hypercalcaemia, abnormal liver and renal function, and urinary calculus in different groups. Transvaginal ultrasound examinations will be performed by a well-experienced physician in gynaecology. If possible, the same examiner should conduct all examinations of a subject and the same ultrasound machine should be used throughout the study.

Withdrawal

Subjects must be withdrawn from the study when one of the following criteria occurs:

1. At their own request. At any time during the study and without giving reasons, a subject may decline to participate further. The subject will not suffer any disadvantages as a result.

2. In the investigator's opinion, continuation of the study treatment would be harmful to the subject's health.

3. Patients with poor compliance.

4. Lost to follow-up.

5. Pregnancy.

6. Receive other medical treatments which may affect the level of serum 25-hydroxyvitamin D3 or other surgical treatments.

7. The level of serum calcium $>3.5 \mathrm{mmol} / \mathrm{L}$ or serum 25-hydroxyvitamin D3 $>150 \mathrm{ng} / \mathrm{mL}$.

\section{Safety assessments}

Safety of vitamin D administrated in patients without UFs will be assessed by renal and liver function test, serum electrolyte (sodium, chloride, potassium, calcium and phosphorus), blood routine test and serum 25-hydroxyvitamin $\mathrm{D}_{3}$. Urine pregnancy test and serum 25-hydroxyvitamin $\mathrm{D}_{3}$ level will be detected every 3 months. Other indicators will be detected during the period of screening and after the treatment of every 6 months. Liver and urinary system ultrasound will be conducted after the treatment of 12 months and 24 months. The occurrence of any adverse events in trial participants will be recorded in the case report forms during each patient visit. Patients will be withdrawn who have severe adverse events, as it is unsafe for them to continue the trial. Meanwhile, we will give them relevant medical care and follow them up until the reaction has terminated.

Part II: association between vitamin D and the development of UFs

Study objectives

The primary objective of this part is to assess the association of supplementation with vitamin $\mathrm{D}$ on inhibiting 
the development of UFs within 1 year and 2 years. The secondary objective of part II is to evaluate the safety of supplementation with vitamin D in UFs subjects.

\section{Trial design}

After signing of informed consent, UFs patients with vitamin D deficiency $(12 \mathrm{ng} / \mathrm{mL} \leq$ serum 25-hydroxyvitamin $\mathrm{D}_{3} \leq 20 \mathrm{ng} / \mathrm{mL}$ ) will be randomly assigned in a 1:1 ratio to intervention group A or control group B. Intervention group A will accept an oral dose of 1600 IU (four capsules)/day vitamin $\mathrm{D}_{3}$ for up to 2 years. Control group $\mathrm{B}$ will receive 2-year follow-up. UFs patients with vitamin D insufficiency $(21 \mathrm{ng} / \mathrm{mL}$ s serum 25-hydroxyvitamin $\mathrm{D}_{3} \leq 29 \mathrm{ng} / \mathrm{mL}$ ) will be randomly assigned in a $1: 1$ ratio to intervention group $\mathrm{C}$ or control group $\mathrm{D}$. Intervention group $\mathrm{C}$ will accept an oral dose of $800 \mathrm{IU}$ (two capsules) / day vitamin $\mathrm{D}_{3}$ for up to 2 years. Control group $\mathrm{D}$ will receive 2-year follow-up. Gynaecological ultrasound examinations will be performed every 3 months. The number, location and size of the UFs will be documented (the transverse, longitudinal and antero-posterior diameters of fibroids will be documented at each efficacy ultrasound examination for volume calculation). The safety of vitamin D in subjects with UFs will be evaluated, including blood routine examination, serum electrolyte, hepatic and renal function, liver and urinary system ultrasound, and serum 25-hydroxyvitamin $\mathrm{D}_{3}$. Vitamin $\mathrm{D}_{3}$ soft capsules (400 IU per capsale) are purchased from Sinopharm star shark pharmaceutical (Xiamen, China). An overview of the study design is shown in figure 2 and table 3 .

\section{Sample size}

According to a previous study, the volume of UFs was $8.2(2.1-30.5) \mathrm{cm}^{3}$ after the supplement of vitamin D for

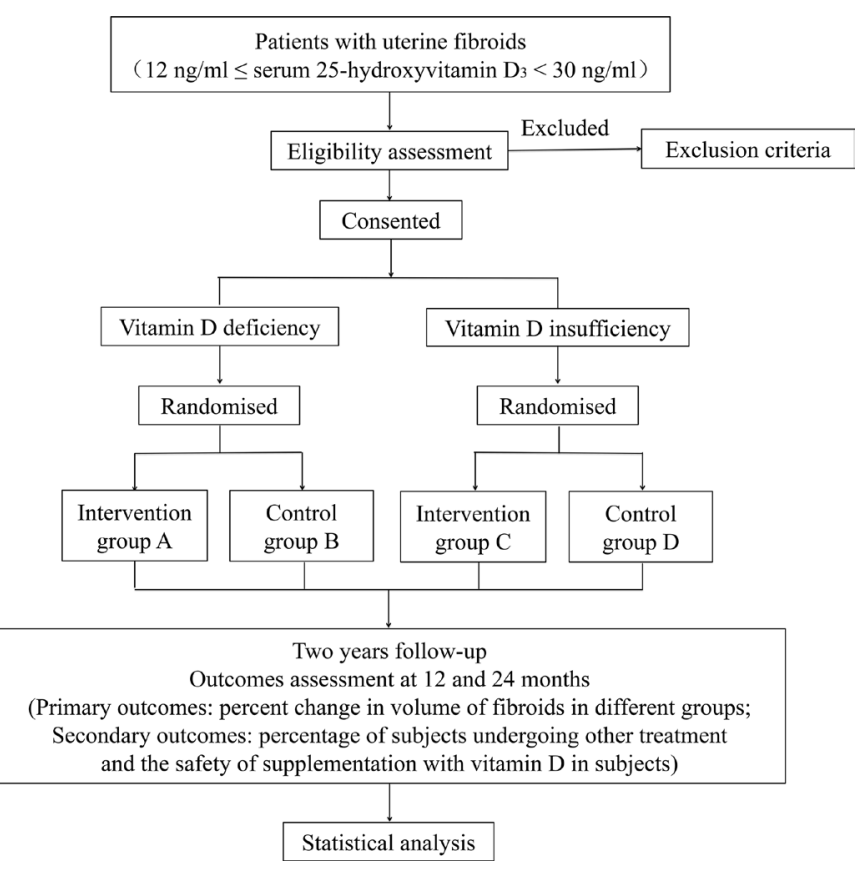

Figure 2 Flow chart showing the steps of part II in participant recruitment, treatment and analysis.
Table 3 Flow chart of the study showing timing collection of different variables

\begin{tabular}{|c|c|c|c|c|c|c|c|c|c|}
\hline Follow-up & 1 & 2 & 3 & 4 & 5 & 6 & 7 & 8 & 9 \\
\hline Months & 0 & 3 & 6 & 9 & 12 & 15 & 18 & 21 & 24 \\
\hline Informed consent & $x$ & & & & & & & & \\
\hline Medical history & $x$ & & & & & & & & \\
\hline Physical examination & $x$ & $x$ & $x$ & $x$ & $x$ & $x$ & $x$ & $x$ & $x$ \\
\hline $\begin{array}{l}\text { Serum } \\
\text { 25-hydroxyvitamin } D_{3}\end{array}$ & $x$ & $x$ & $x$ & $x$ & $x$ & $x$ & $x$ & $x$ & $x$ \\
\hline Urine pregnancy test & $x$ & $x$ & $x$ & $x$ & $x$ & $x$ & $x$ & $x$ & $x$ \\
\hline Gynecologic ultrasound & $x$ & $x$ & $x$ & $x$ & $x$ & $x$ & $x$ & $x$ & $x$ \\
\hline $\begin{array}{l}\text { Hepatic and renal } \\
\text { function }\end{array}$ & $x$ & & $x$ & & $x$ & & $x$ & & $x$ \\
\hline Electrolyte & $x$ & & $x$ & & $x$ & & $x$ & & $x$ \\
\hline $\begin{array}{l}\text { Blood routine } \\
\text { examination }\end{array}$ & $x$ & & $x$ & & $x$ & & $x$ & & $x$ \\
\hline $\begin{array}{l}\text { Liver and urinary } \\
\text { system ultrasound }\end{array}$ & $x$ & & & & $x$ & & & & $x$ \\
\hline Side effect assessment & & $x$ & $x$ & $x$ & $x$ & $x$ & $x$ & $x$ & $x$ \\
\hline Changes in menstruation & & $x$ & $x$ & $x$ & $x$ & $x$ & $x$ & $x$ & $x$ \\
\hline $\begin{array}{l}\text { Adverse event } \\
\text { assessment }\end{array}$ & & $x$ & $x$ & $x$ & $x$ & $x$ & $x$ & $\mathrm{x}$ & $x$ \\
\hline $\begin{array}{l}\text { Vitamin D receptor } \\
\text { genotype }\end{array}$ & $x$ & & & & & & & & \\
\hline
\end{tabular}

12 months and $11.4(5.5-22.3) \mathrm{cm}^{3}$ in the control group after 12 months follow-up, respectively. ${ }^{26}$ On the basis of a 0.9 power to detect a significant difference $(\alpha=0.05$, one sided), 320 participants will be required for the four groups in a 1:1:1:1 ratio. Allowing for a $10 \%$ withdrawal rate, we plan to enrol 360 patients in the whole trial (90 randomised to each arm).

\section{Inclusion criteria}

1. Patients are willing to cooperate with the follow-up and sign an informed consent.

2. Married females aged $35-50$ who are diagnosed as UFs by transvaginal ultrasonography.

3. The maximum average diameter of intramural myoma is $\leq 4 \mathrm{~cm}, \geq 1 \mathrm{~cm}$.

4. Serum 25-hydroxyvitamin $\mathrm{D}_{3} \geq 12 \mathrm{ng} / \mathrm{mL}, \leq 29 \mathrm{ng} / \mathrm{mL}$.

\section{Exclusion criteria}

1. Women with serum 25-hydroxyvitamin $\mathrm{D}_{3}<12 \mathrm{ng} / \mathrm{mL}$ or $>29 \mathrm{ng} / \mathrm{mL}$.

2. $\mathrm{BMI}<18.5 \mathrm{~kg} / \mathrm{m}^{2}$ or $\mathrm{BMI}>25 \mathrm{~kg} / \mathrm{m}^{2}$.

3. Patients with heavy menstrual bleeding $(>80.0 \mathrm{~mL})$ per menstrual period, menstrual disorders, pelvic discomfort, infertility or other indications for operation.

4. Patients complicated with leiomyoma degeneration and adenomyosis that were suspected or diagnosed by transvaginal ultrasound or gynaecological examination.

5. Allergic to vitamin $\mathrm{D}_{3}$ soft capsules. 
6. Use of sexual hormone, mifepristone, GnRHa or other medication which is likely to interfere with UFs in the past 3 months.

7. Pregnancy, lactation, postmenopause or planned pregnancy within 2 years.

8. Suspected or identified as other tumours of genital tract.

9. History of osteoporosis or vitamin D deficiency taking vitamin D supplements within previous 1 month.

10. History of autoimmune diseases, infectious diseases (tuberculosis, AIDS), autoimmune diseases, digestive system diseases (malabsorption, Crohn's disease and dysentery).

11. ALT or AST more than 3 times of the normal upper limit, TBIL more than 2 times of the normal upper limit.

12. Creatinine levels $\geq 1.4 \mathrm{mg} / \mathrm{dL}(123 \mu \mathrm{mol} / \mathrm{l})$ or creatinine clearance $\leq 50 \mathrm{~mL} / \mathrm{min}$.

13. History of malignant tumours.

14. Some cases those uteruses are difficult to scan or the amount of UFs is more than 4.

15. Simultaneous participation in another clinical study with investigational medicinal product(s).

\section{Outcomes measures}

Primary outcomes: percent change in volume of the largest fibroid and total fibroids compared with baseline (baseline=last value obtained before randomisation; measured by ultrasound examination). The volume of the largest uterine leiomyoma (in $\mathrm{cm}^{3}$ ) was calculated with the following formula:

$$
\text { volume }=\frac{4 \pi}{3} \times \frac{a}{2} \times \frac{b}{2} \times \frac{c}{2}=\frac{\pi \cdot a \cdot b \cdot c}{6}
$$

Secondary outcomes: percentage of subjects undergoing other medical or surgical treatment, hypercalcaemia, urinary calculus, abnormal liver and renal function. Transvaginal ultrasound examinations will be performed by a well-experienced gynaecologist. If possible, the same examiner should conduct all examinations for each subject throughout the study and the same ultrasound machine should be used throughout the study.

\section{Withdrawal}

Subjects must be withdrawn from the study when one of the following criteria occurs:

1. At their own request. At any time during the study and without giving reasons, a subject may decline to participate further. The subject will not suffer any disadvantages as a result.

2. In the investigator's opinion, continuation of the study treatment would be harmful to the subject's health.

3. Patients with poor compliance.

4. Lost to follow-up.

5. Pregnancy.

6. Other medical or surgical treatments for UFs.
7. Receive other medical treatments which may affect the level of serum 25-hydroxyvitamin $\mathrm{D}_{3}$ or other surgical treatments.

8. The level of serum calcium $>3.5 \mathrm{mmol} / \mathrm{L}$ or serum 25-hydroxyvitamin $\mathrm{D}_{3}>150 \mathrm{ng} / \mathrm{mL}$.

\section{Safety assessments}

Safety of vitamin D administrated in patients with UFs will be assessed by the same methods as part I.

\section{Treatment compliance assessment}

All research medications (vitamin $\mathrm{D}_{3}$ soft capsules) should be recorded. Standard with good compliance is defined as: $80 \%$ sactual oral dose/dose $\times 100 \% \leq 120 \%$. Criteria for poor compliance is as follows: actual oral dose/dose * $100 \% \leq 80 \%$ or actual oral dose $/$ dose $\times 100 \% \geq 120 \%$. Each follow-up should be based on the number of returned study drugs to determine the drug compliance. Subjects should return all unused research drugs and empty packages of used drugs every follow-up.

\section{Statistical analysis}

Statistical analyses will be performed using SPSS V.22.0 for Windows (SPSS). The randomisation sequence is generated by the use of the random number table. The normal distribution of continuous variables is tested by onesample Kolmogorov-Smirnov test. Continuous variables with normal distribution are reported as mean (SD); nonnormal variables are presented as median (IQR). Means of 2 and 3 or more continuous normally distributed variables, respectively, are compared by independent samples Student's t-test or one-way analysis of variance test. MannWhitney U test and Kruskal-Wallistest are used, respectively, to compare means of 2 and 3 or more groups of variables that are not normally distributed. The frequencies of categorical variables are compared using Pearson $\chi^{2}$ or Fisher's exact test, when appropriate. A $p<0.05$ is considered statistical significance.

\section{Ethics and dissemination}

The study has been approved by the ethics committee of the Second Affiliated Hospital of Wenzhou Medical University (No. LCKY2018-35) and registered in the United States National Institutes of Health Clinical Trials Registry: NCT03586947 and NCT03584529. The procedure will be performed following the principles described in the declaration of helsinki. We will publish the results of this study in peer-reviewed journals and related websites.

\section{No patient and public involvement}

There were no funds or time allocated for patient and public involvement so we were unable to involve patients. We have invited patients to help us develop our dissemination strategy.

\section{DISCUSSION}

There is an increasing awareness that vitamin D deficiency is associated with many health outcomes. Up 
to now, the roles of vitamin D in calcium homeostasis and bone health have been well characterised. ${ }^{29}$ In the last decade, it has been recognised that vitamin $\mathrm{D}$ also prevented cardiovascular diseases, infections, adverse pregnancy outcomes and tumours. ${ }^{30} 31$ Nevertheless, the cut-off thresholds for vitamin D deficiency and optimal levels are still controversial. The guideline of The Endocrine Society suggests vitamin $\mathrm{D}$ insufficiency is defined as a serum 25-hydroxyvitamin $\mathrm{D}_{3}$ of $21-29 \mathrm{ng} / \mathrm{mL}$, and vitamin $\mathrm{D}$ deficiency as a serum 25-hydroxyvitamin $\mathrm{D}_{3}$ below $20 \mathrm{ng} / \mathrm{mL}^{32}$ The guideline also recommends that patients with vitamin $\mathrm{D}$ deficiency should be treated with $50000 \mathrm{IU}$ of vitamin D once a week for 8 weeks to achieve a blood level of serum 25-hydroxyvitamin $\mathrm{D}_{3}$ above $30 \mathrm{ng}$ / $\mathrm{mL}$, followed by maintenance therapy of 1500-2000 IU/ day. Patients with vitamin $\mathrm{D}$ insufficiency require at least $600 \mathrm{IU} /$ day of vitamin $\mathrm{D}$ for the prevention of vitamin D deficiency. ${ }^{32}$ In fact, the level of serum 25-hydroxyvitamin $\mathrm{D}_{3}$ varies from race to race. It is reported that caucasian females have higher serum 25-hydroxyvitamin $\mathrm{D}_{3}$ concentrations than the others. ${ }^{33}{ }^{34}$ According to the guideline of Institute of Medicine, however, vitamin D deficiency is defined as a serum 25-hydroxyvitamin $\mathrm{D}_{3}$ below $12 \mathrm{ng} / \mathrm{mL}$, and vitamin $\mathrm{D}$ insufficiency as a serum 25-hydroxyvitamin $\mathrm{D}_{3}$ of $12-20 \mathrm{ng} / \mathrm{mL} .{ }^{35}$ Specialists from Osteoporosis Committee of China Gerontological Society recommend that patients with high risks (history of osteoporosis, inadequate sun exposure, use of glucocorticoid, etc) whose blood levels of serum 25-hydroxyvitamin $\mathrm{D}_{3}$ are between 12 and $20 \mathrm{ng} / \mathrm{mL}$ should receive at least $600 \mathrm{IU} /$ day vitamin D supplementation. ${ }^{36}$ Patients with blood levels of serum 25-hydroxyvitamin $\mathrm{D}_{3}$ exceed $20 \mathrm{ng} /$ $\mathrm{mL}$ could obtain an adequate amount of vitamin $\mathrm{D}$ from dietary sources and sun exposure ${ }^{36}$ It is reported that the single-nucleotide polymorphisms in vitamin $\mathrm{D}$ receptor genes modified the efficacy of vitamin $\mathrm{D}_{3}$ supplementation to increase circulating serum 25-hydroxyvitamin $\mathrm{D}_{3}$ levels. ${ }^{37}$ To determine the potential relationship between them, the vitamin D receptor genotype of all patients will be tested. Females over the age of 35 years are more likely to suffer from UFs. Furthermore, postmenopause and pregnancy might affect the development and progression of UFs. ${ }^{1}$ So the females aged $35-50$ years are chosen in this trial. We will exclude patients who are pregnant, lactant, postmenopausal, or planned pregnancy within 2 years. In this study, patients with vitamin D deficiency or insufficiency will receive adequate vitamin D supplementation. Dietary vitamin D intake and other supplements of vitamin $\mathrm{D}$ will be limited.

In conclusion, this is the first study protocol of an openlabel, randomised controlled trial to evaluate the efficacy and safety of vitamin D supplementation in preventing and inhibiting the UFs. However, our study should be interpreted within the context of two limitations. First, the trial is not a double-blind, placebo-controlled trial. Furthermore, another limitation is that the trial is implemented in only one hospital. Notwithstanding these limitations, the results from this study will provide new evidences about vitamin D preparations in UFs from a well-designed trial. Once our hypothesis is confirmed, this study will provide a more effective, safe, and low-cost therapy in the prevention and treatment of UFs.

Correction notice This article has been corrected since it was published. First affiliation has been updated.

Author Contributions $\mathrm{XZ}$ is the principal investigator of this study and refined the protocol. SB and YS wrote the manuscript and contributed to the design of the study. SB will recruit the patients and conduct the trial. YS, XZ and YL will supervise the trial. CJ, the medical statistician for the study, will contribute to the statistical design and analysis of data. All authors have revised the protocol critically for important intellectual content and approved the final manuscript.

Funding This work was supported by the clinical trial centre of the Second Affiliated Hospital of Wenzhou Medical University (No: SAHoWMU-CR2017-07-101) and grants from Wenzhou Science and Technology Grant (Y20170604).

Disclaimer Sponsors of the study had no involvement in the collection, analysis, and interpretation of data or the writing of the manuscript.

Competing interests None declared.

Patient consent for publication Not required.

Provenance and peer review Not commissioned; externally peer reviewed.

Open access This is an open access article distributed in accordance with the Creative Commons Attribution Non Commercial (CC BY-NC 4.0) license, which permits others to distribute, remix, adapt, build upon this work non-commercially, and license their derivative works on different terms, provided the original work is properly cited, appropriate credit is given, any changes made indicated, and the use is non-commercial. See: http://creativecommons.org/licenses/by-nc/4.0/.

\section{ORCID iD}

Xueqiong Zhu http://orcid.org/0000-0002-8389-928X

\section{REFERENCES}

1 Stewart EA, Cookson CL, Gandolfo RA, et al. Epidemiology of uterine fibroids: a systematic review. BJOG 2017;124:1501-12.

2 Dagur G, Suh Y, Warren K, et al. Urological complications of uterine leiomyoma: a review of literature. Int Urol Nephrol 2016;48:941-8.

3 Vilos GA, Allaire C, Laberge P-Y, et al. The management of uterine leiomyomas. J Obstet Gynaecol Can 2015;37:157-78.

4 Donnez J, Dolmans M-M. Uterine fibroid management: from the present to the future. Hum Reprod Update 2016;22:665-86.

5 Malik M, Britten J, Cox J, et al. Gonadotropin-releasing hormone analogues inhibit leiomyoma extracellular matrix despite presence of gonadal hormones. Fertil Steril 2016;105:214-24.

6 Ali M, Chaudhry ZT, Al-Hendy A. Successes and failures of uterine leiomyoma drug discovery. Expert Opin Drug Discov 2018;13:169-77.

7 Shen Q, Hua Y, Jiang W, et al. Effects of mifepristone on uterine leiomyoma in premenopausal women: a meta-analysis. Fertil Steril 2013;100:1722-6.

8 Liu C, Lu Q, Qu H, et al. Different dosages of mifepristone versus enantone to treat uterine fibroids: a multicenter randomized controlled trial. Medicine 2017;96:e6124.

9 Shen $Q$, Shu L, Luo H, et al. The use of mifepristone in abortion associated with an increased risk of uterine leiomyomas. Medicine 2017;96:e6680.

10 Commandeur AE, Styer AK, Teixeira JM. Epidemiological and genetic clues for molecular mechanisms involved in uterine leiomyoma development and growth. Hum Reprod Update 2015;21:593-615.

11 Chen W, Ohara N, Wang J, et al. A novel selective progesterone receptor modulator asoprisnil (J867) inhibits proliferation and induces apoptosis in cultured human uterine leiomyoma cells in the absence of comparable effects on myometrial cells. J Clin Endocrinol Metab 2006;91:1296-304

12 Murphy AA, Kettel LM, Morales AJ, et al. Regression of uterine leiomyomata in response to the antiprogesterone RU 486. J Clin Endocrinol Metab 1993;76:513-7.

13 Murii A, Whitaker L, Chow TL, et al. Selective progesterone receptor modulators (SPRMs) for uterine fibroids. Cochrane Database Syst Rev 2017;4:CD010770.

14 Melis GB, Neri M, Piras B, et al. Vilaprisan for treating uterine fibroids. Expert Opin Investig Drugs 2018;27:497-505. 
15 Parazzini F, Di Martino M, Candiani M, et al. Dietary components and uterine leiomyomas: a review of published data. Nutr Cancer 2015;67:569-79.

16 Ciebiera M, Łukaszuk K, Męczekalski B, et al. Alternative oral agents in prophylaxis and therapy of uterine Fibroids-An up-to-date review. Int J Mol Sci 2017;18

17 Baird DD, Hill MC, Schectman JM, et al. Vitamin D and the risk of uterine fibroids. Epidemiology 2013;24:447-53.

18 Ciebiera M, Włodarczyk M, Słabuszewska-Jóźwiak A, et al. Influence of vitamin $D$ and transforming growth factor $\beta 3$ serum concentrations, obesity, and family history on the risk for uterine fibroids. Fertil Steril 2016;106:1787-92.

19 Bläuer M, Rovio PH, Ylikomi T, et al. Vitamin D inhibits myometrial and leiomyoma cell proliferation in vitro. Fertil Steril 2009;91:1919-25.

20 Halder SK, Goodwin JS, Al-Hendy A. 1,25-Dihydroxyvitamin D3 reduces TGF-beta3-induced fibrosis-related gene expression in human uterine leiomyoma cells. J Clin Endocrinol Metab 2011;96:E754-62.

21 Halder SK, Sharan C, Al-Hendy A. 1,25-Dihydroxyvitamin D3 treatment shrinks uterine leiomyoma tumors in the Eker rat model. Biol Reprod 2012;86:116.

22 Halder SK, Sharan C, Al-Hendy O, et al. Paricalcitol, a vitamin D receptor activator, inhibits tumor formation in a murine model of uterine fibroids. Reprod Sci 2014;21:1108-19.

23 Corachán A, Ferrero $\mathrm{H}$, Aguilar A, et al. Inhibition of tumor cell proliferation in human uterine leiomyomas by vitamin $D$ via $W n t / \beta$ catenin pathway. Fertil Steril 2019;111:397-407.

24 Corachán A, Ferrero $\mathrm{H}$, Escrig J, et al. Long-term vitamin D treatment decreases human uterine leiomyoma size in a xenograft animal model. Fertil Steril 2020;113:205-16.

25 Li S, Chen B, Sheng B, et al. The associations between serum vitamin $D$, calcium and uterine fibroids in Chinese women: a casecontrolled study. J Int Med Res 2020;48:300060520923492.

26 Ciavattini A, Delli Carpini G, Serri M, et al. Hypovitaminosis D and "small burden" uterine fibroids: Opportunity for a vitamin D supplementation. Medicine 2016;95:e5698.

27 Arjeh S, Darsareh F, Asl ZA, et al. Effect of oral consumption of vitamin D on uterine fibroids: a randomized clinical trial. Complement Ther Clin Pract 2020;39:101159.

28 Brakta S, Diamond JS, Al-Hendy A, et al. Role of vitamin D in uterine fibroid biology. Fertil Steril 2015;104:698-706.

29 Fleet JC. The role of vitamin D in the endocrinology controlling calcium homeostasis. Mol Cell Endocrinol 2017;453:36-45.

30 Faridi KF, Lupton JR, Martin SS, et al. Vitamin D deficiency and nonlipid biomarkers of cardiovascular risk. Arch Med Sci 2017;13:732-7.

31 Akoh CC, Pressman EK, Cooper E, et al. Low vitamin D is associated with infections and proinflammatory cytokines during pregnancy. Reprod Sci 2018;25:414-23.

32 Holick MF, Binkley NC, Bischoff-Ferrari HA, et al. Evaluation, treatment, and prevention of vitamin D deficiency: an endocrine Society clinical practice guideline. J Clin Endocrinol Metab 2011;96:1911-30.
33 Alzaman NS, Dawson-Hughes B, Nelson J, et al. Vitamin D status of black and white Americans and changes in vitamin D metabolites after varied doses of vitamin D supplementation. Am J Clin Nutr 2016;104:205-14.

34 Powe CE, Evans MK, Wenger J, et al. Vitamin D-binding protein and vitamin D status of black Americans and white Americans. $N$ Engl J Med 2013;369:1991-2000.

35 Aspray TJ, Bowring C, Fraser W, et al. National osteoporosis Society vitamin D guideline summary. Age Ageing 2014;43:592-5.

36 Liao X, Zhang Z, Zhang H, et al. Application guideline for vitamin D and bone health in adult Chinese (2014 standard edition). Chinese Journal of Osteoporosis 2014;20:1011-30.

37 Barry EL, Rees JR, Peacock JL, et al. Genetic variants in CYP2R1, CYP24A1, and VDR modify the efficacy of vitamin D3 supplementation for increasing serum 25-hydroxyvitamin D levels in a randomized controlled trial. J Clin Endocrinol Metab 2014;99:E2133-7.

38 de Boer IH, Zelnick LR, Ruzinski J, et al. Effect of vitamin D and omega-3 fatty acid supplementation on kidney function in patients with type 2 diabetes: a randomized clinical trial. JAMA 2019;322:1899.

39 Burt LA, Billington EO, Rose MS, et al. Effect of high-dose vitamin D supplementation on volumetric bone density and bone strength: a randomized clinical trial. JAMA 2019;322:736-45.

40 Urashima M, Ohdaira H, Akutsu T, et al. Effect of vitamin D supplementation on relapse-free survival among patients with digestive tract cancers: the AMATERASU randomized clinical trial. JAMA 2019;321:1361-9.

41 Scragg R, Khaw K-T, Toop L, et al. Monthly high-dose vitamin $\mathrm{D}$ supplementation and cancer risk: a post hoc analysis of the vitamin D assessment randomized clinical trial. JAMA Oncol 2018:4:e182178.

42 Aglipay M, Birken CS, Parkin PC, et al. Effect of high-dose vs standard-dose Wintertime vitamin D supplementation on viral upper respiratory tract infections in young healthy children. JAMA 2017;318:245-54.

43 Zittermann A, Ernst JB, Prokop S, et al. Effect of vitamin D on allcause mortality in heart failure (EVITA): a 3-year randomized clinical trial with $4000 \mathrm{IU}$ vitamin D daily. Eur Heart $J$ 2017;38:2279-86.

44 Lappe J, Watson P, Travers-Gustafson D, et al. Effect of vitamin D and calcium supplementation on cancer incidence in older women: a randomized clinical trial. JAMA 2017;317:1234-43.

45 Arora $\mathrm{P}$, Song $\mathrm{Y}$, Dusek J, et al. Vitamin D therapy in individuals with prehypertension or hypertension: the DAYLIGHT trial. Circulation 2015;131:254-62.

46 Rusińska A, Płudowski P, Walczak M, et al. Vitamin D supplementation guidelines for general population and groups at risk of vitamin D deficiency in Poland-Recommendations of the Polish Society of pediatric endocrinology and diabetes and the expert panel with participation of national specialist consultants and representatives of scientific Societies-2018 update. Front Endocrino 2018;9:246 